Pereverzieva, A. and Volkov, V. (2020), "Assessment method of social entrepreneurship nature and its development”, Management and entrepreneurship: trends of development, Vol. 1, Issue 11, pp. 113-131, DOI: https://doi.org/10.26661/2522-1566/2020-1/11-08

ENTREPRENEURSHIP, TRADE AND EXCHANGE ACTIVITIES

\section{RECEIVED:}

18 February 2020

ACCEPTED:

28 March 2020

RELEASED:

20 April 2020
UDC 334

DOI 10.26661/2522-1566/2020-1/11-08

\title{
ASSESSMENT METHOD OF SOCIAL ENTREPRENEURSHIP NATURE AND ITS DEVELOPMENT
}

\author{
Anna Pereverzieva \\ Zaporizhzhia national university \\ Zaporizhzhia, Ukraine \\ ORCID ID: 0000-0001-8391-6636
}

\author{
Volodymyr Volkov \\ Zaporizhzhia national university \\ Zaporizhzhia, Ukraine \\ ORCID ID: 0000-0002-1270-895X
}

*Corresponding author email: pereverzeva@ukr.net

\begin{abstract}
The study of social entrepreneurship and the assessment of its necessity caused by socio-economic problems like low level of household purchasing power and state failure to solve is relevant. The need to introduce and develop social entrepreneurship requires favourable environment in the country, determined by state support, public acceptance and availability of potential investors. The phenomenon of social entrepreneurship in the economy has dual nature: it contributes to full satisfaction of households` basic needs and ensures social entrepreneur`s selfrealization. Social enterprise provides both non-commercial and commercial activity. A non-profit component is a key one in the European model of social entrepreneurship. Assessment of nature and opportunities of social enterprises development allows to reach the principle of "need-opportunity" balance aimed at effective management decision-making regarding the expediency to introduce the form of business in the country. If there is a need for social entrepreneurship national economy demands building favourable environment for its functioning and development. The study purpose is to propose the assessment method of social entrepreneurship nature and its development and the necessity of its application around the world, to single out conditions for its development to solve socio-economic problems and move towards the economy with a human face. The study object is scientific and practical basis of social entrepreneurship development in the context of the necessity of its implementation and operating environment. Methodology: comprehensive assessment approach has been used in the study. It comprises different methods, namely: the index method (to calculate sub-indices and the overall index, to make single system design to facilitate comparison); the matrix method (grouping of countries according to their changing need for social entrepreneurship); multiplicative model (analytical toolkit to determine overall index to estimate the contribution of each indicator simultaneously). The study result is the assessment method of social entrepreneurship nature and development implemented in the EU. Conclusions: it has been determined that during 2016 and 2019, with a lag of three years, a third of European countries have changed their attitude towards social entrepreneurship. Some countries have increased their need for social enterprises, but favourable conditions for their development have not been built. Other countries have been improving environment for social enterprise activities, but their demand has been diminishing. The growing need for social enterprises in one third of the countries has been accompanied by favourable environment for their activity and development. Scientific and practical relevance is the possibility to apply the proposed method for any country or group of
\end{abstract}


countries with similar level of economic development to prove the relevance of social entrepreneurship implementation as innovation form of business, to identify the terms of its advantageous development in the long period and to build the strategy of social enterprises operations and their management.

Keywords: social entrepreneurship, index, EU countries, development, need for social entrepreneurship, business environment with a human face.

JEL Classification: L31, O11, O15.

\section{INTRODUCTION}

The current stage of entrepreneurial activity is characterized by plunging spending power of population, significant differentiation of income distribution, higher poverty and unemployment rate, which will require new balanced mechanisms for the development of national economies, and as a result harmonization of the world development. According to the World Bank statistics, about $46 \%$ of the world's population is living on less than $\$ 5.5$ a day (World Bank, 2018). The average unemployment rate in the world has reached 5.6\% (International Labour Organization, 2018). According to ILO experts, the tendency for significant increase in the number of unemployed and resource base contraction of national economies is displayed in many regions of the world.

The need to solve common problems of entrepreneurship produces the demand for effective ways of controlled development of the world economy in general and individual national economies in particular. Interdependence and level of economic openness, the need to solve common problems form single system and develop successes and failures globally.

Traditional managerial methods have proved their ineffectiveness when meeting needs of population, satisfaction of personal and public interests. One of the necessary hard factors is introduction and development of social entrepreneurship as one of the advanced forms of economic activity to ensure socio-economic development. In this case, the innovative form of business can not completely offset existing problems, but can minimize their negative impact by successful combination of creative business model with market-based management methods. The duality of social enterprises lies not only in combination of commercial and non-commercial goals, but also in the balance between public (solving socio-economic problems) and personal development of an entrepreneur (vigor, self-realization, self-improvement, social consciousness).

Within the study`s framework, we formulate several hypotheses regarding the nature and further development of social entrepreneurship:

Hypothesis 1 (H1): higher unemployment rate requires enhancing development of social entrepreneurship.

Hypothesis 2 (H2): higher income levels reduce the need for social entrepreneurship.

Hypothesis 3 (H3): the more favourable environment for social entrepreneurship a country has, the less is need for it.

\section{LITERATURE REVIEW}

The issue of theoretical research of social enterprises and its relevance amid limited financial resources make it impossible to meet primary human needs at the state level. Practical studies pay special attention to the importance of social entrepreneurship when solving different economic level issues.

Social entrepreneurship is a constant study object of foreign and Ukrainian scholars. I.I. Bereznyak (2014), Z.I. Galushka (2013), O.B. Kireeva (2011), V.I. Udodova, V.I. Shapoval (2013) and other Ukrainian scientists have been studying both theoretical and practical aspects of functioning and development of social enterprises. Typically, scholars analyze 
Pereverzieva, A. and Volkov, V. (2020), "Assessment method of social entrepreneurship nature and its development”, Management and entrepreneurship: trends of development, Vol. 1, Issue 11, pp. 113-131, DOI: https://doi.org/10.26661/2522-1566/2020-1/11-08

and complement the concept of "social entrepreneurship", demonstrate relevance of its functioning and development in order to reduce the degree of uncertainty and risk in the context of growing impact of global trends.

Monica Nandan, Tricia B. Bent-Goodley and Gokul Mandayam (2019) conducted thorough analysis of social entrepreneurship and features of the portfolio of social values formation. Scientists study the tendencies of social entrepreneurship development at the current stage of economic development; determine peculiarities of this business form organization by building innovative strategies to solve complex social issues. Foreign authors develop concepts, principles, skills and practical examples of successful functioning of social enterprises in different countries around the world. Scholars say that social entrepreneurs are agents of change who try to challenge the hypothetical assumption of contradiction between social goods and entrepreneurship. This idea is confirmed by the study of Byungchae Jin (2019), who found out the correlation between the direct impact of social entrepreneurs`intellectual abilities and the effectiveness in management to combine social and economic goals. Besides, Grimes M., Vogus T. J., McMullen J. S. and Miller T. L. (2013) emphasize that nowadays a social entrepreneur is usually a "built-in agent", a highly motivated person willing to take on this role.

Dahiya V.S. (2019) considers a social enterprise as an alternative way to solve social issues by means of efficient business models and market economy in case the state cannot provide full satisfaction of all human needs. This can be achieved, according to Battilana J. and Lee M. (2014) by the combination of organizational forms of business and charity. This makes social enterprises the ideal type of a hybrid organization.

The need for widespread of social entrepreneurship is proved by Corner P.D. and Kearins K. (2018), who confirmed direct correlation between the number of social enterprises and social problems that got solved.

Dacin T., Dacin M. and Tracey P. (2011) studied controversial aspects of social enterprises functioning, analyzing advantages and disadvantages of this form of business and determining the future prospects for its development.

Chandra Y. (2017) devoted his research to psychological impact of social entrepreneurship. The scientist argued that social entrepreneurship is able to create self-confidence, avoid certain ideological constraints, but also to form new life purpose, new social roles and connections that provide the platform for shaping a new future. This is important, because social entrepreneurship, as a form of business organization, provides autonomy focused on profitability and a high level of emancipation for both entrepreneurs and those they serve.

Analysis of theoretical and practical studies of social entrepreneurship proves the importance of the form of business organization amid plunging spending power of households and sustainably high economic uncertainty. The need for social entrepreneurship allows the country to justify the relevance of the form of economic activity`s support depending on economic characteristics and its internal environment, to assess social entrepreneurship impact on households` topical socioeconomic issues. Positive decisions concerning formation and step-up of social enterprises requires governments to build appropriate environment and favourable conditions for doing business. Our assumptions confirm the relevance of the study and act as motivation for it.

\section{PAPER OBJECTIVE}

In the context of growing impact of global challenges and inability to fully take into account socio-economic outcomes for national economies, the issue arises to find and implement alternative options for maintaining standard of living and quality of life. Social entrepreneurship is an effective tool to address this issue, taking into consideration the scarcity of material and intangible resources. It helps to meet needs of people to optimize the cost of resources and fulfill their opportunities. The purpose of the article is to assess the nature and development of social entrepreneurship at the national level and to provide comparative analysis of the long-term benefits of this business form. 


\section{METHODOLOGY}

Quantitative and qualitative methods have been applied for a more complete analysis of social entrepreneurship as there is the need for its introduction and formation of favourable environment for its further development. The integrated approach is determined by the peculiarities of national development, internal business environment, the nature of current issues, as well as by set development priorities. In the article we consider the assessment of social entrepreneurship`s nature and development: the case of the EU countries. Let us note that this toolkit can be extended to any country or groups of countries having approximately the same level of economic development. The algorithm of social entrepreneurship`s nature and development assessment involves the following stages:

1) to identify indicators that determine the need for social entrepreneurship, i.e to recognize problems (weaknesses) that can be solved as the result of formation and development of social enterprises. We propose to distinguish two indicators: unemployment rate and per capita income;

2) normalization, calculation of sub-indices and overall index on the basis of multiplicative model;

3) comparison of the need for social entrepreneurship with its socio-economic environment in European countries on the basis of the matrix method;

4) the comparative analysis of the EU countries` trends regarding the development of social entrepreneurship.

To calculate the sub-indices of the need for social entrepreneurship indicators and to determine the overall indicator, we have used the index method. It is easy to apply it to make single system design to facilitate comparison. To determine the Social Entrepreneurship Need Index for a particular country, we have used the multiplicative model to objectively assess the contribution of each indicator in the overall result. The matrix method allowed to group countries economic indicators on the basis of their comparison, to make comparative analysis of the change of countries` ranking over time regarding their need for social entrepreneurship and, accordingly, to build the environment for its successful development.

\section{RESULT AND DISCUSSION}

Now the development of society faces lower households`standard of living and quality of life, the number of unemployed increases, which automatically leads to the growing number of unresolved socio-economic problems that cause social tension. Social entrepreneurship is an effective tool to avoid the situation or reduce its negative effects. Due to its activities, it is able to meet basic needs and partially solve the problem of unemployment. This stipulates the necessity to test hypotheses $(\mathrm{H} 1, \mathrm{H} 2, \mathrm{H} 3)$.

Let us remind that to study the country's need for social entrepreneurship, we considered two indicators: the unemployment rate and per capita income (Fig. 1). 
Pereverzieva, A. and Volkov, V. (2020), "Assessment method of social entrepreneurship nature and its development”, Management and entrepreneurship: trends of development, Vol. 1, Issue 11, pp. 113-131, DOI:

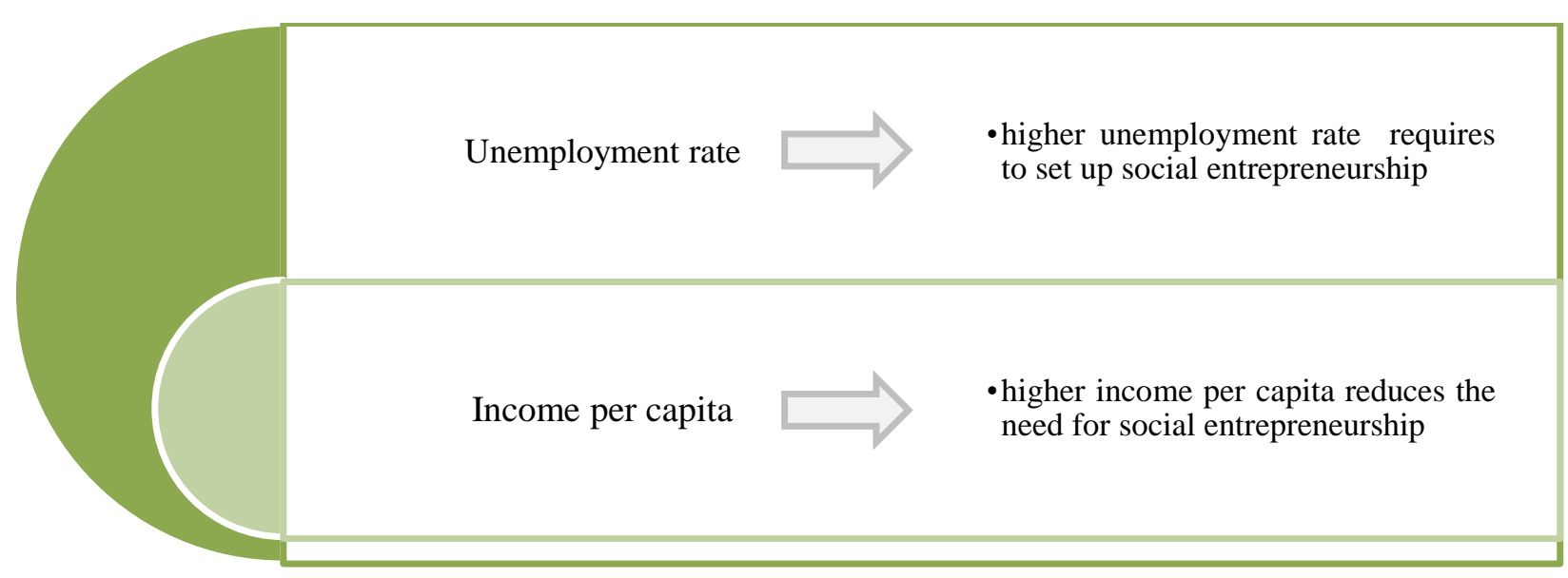

Figure 1. Indicators of assessment of the need for social entrepreneurship

\section{Source: Own compilation}

Figure 1 demonstrates analysis of the demand for social entrepreneurship development aimed to solve the following issues:

- to contract the unemployment rate. Launching new social enterprises induces lager number of jobs and thus causes lower unemployment rate;

- income per capita is tangible indicator which proves positive or negative trends of households` living standards.

Based on the mentioned above indices we propose the calculation methodology of Social Entrepreneurship Need Index.

Calculation methodology of Social Entrepreneurship Need Index includes the next stages:

- to build statistical data base: indicators of unemployment rate and income per capita with a lag of three years: 2013, 2016, 2019 to analyze the dynamic pattern;

- to normalize indices to make single system design;

- to calculate the Social Entrepreneurship Need Index.

Calculations based on the proposed methodology are studied as case of the EU countries.

The social entrepreneurship model of the vast majority of European countries is geared towards non-commercial goals, so amid the decline of Ukrainian households` spending power, it could be optimal pattern of business organization and socio-economic problems solution.

The indicators for calculating the Social Entrepreneurship Need Index are grouped in Table 1.

It should be noted that the unemployment rate in Ukraine in 2013 stood for $7.7 \%$, in 2016 $9.7 \%$, in $2019-9.1 \%$. That is, since 2016, the official unemployment rate in Ukraine has exceeded the EU mean value by 0.9 percentage points, and in 2019 by 2.8 percentage points. According to per capita income, Ukraine is far behind the EU countries: in 2013 - 2989.6 euros, in 2016 - 2317.6 euros, in 2019 - 3638.1 euros. Per capita income in Ukraine is 5 times less than the EU minimum. Based on these statistics, it can be concluded that there is a significant demand of the national economy to introduce social entrepreneurship and form favourable environment for its development. To obtain the objective result and taking into account significant economic lag of Ukraine, the methodology will be tested on the example of the EU countries. 
Indicators for calculating the Social Entrepreneurship Need Index for the EU countries in 2013, 2016 and 2019

\begin{tabular}{|c|l|c|c|c|c|c|c|}
\hline \multirow{2}{*}{ № } & \multirow{2}{*}{ Country } & \multicolumn{2}{|c|}{ Unemployment rate, $\%$} & \multicolumn{3}{c|}{ Income per capita, $€$} \\
\cline { 3 - 8 } & & 2013 & 2016 & 2019 & 2013 & 2016 & 2019 \\
\hline 1 & Austria & 5,4 & 6,0 & 4,5 & 34600 & 35600 & 38600 \\
\hline 2 & Belgium & 8,4 & 7,5 & 5,4 & 31600 & 33500 & 35100 \\
\hline 3 & Bulgaria & 13,8 & 7,6 & 4,2 & 12000 & 13800 & 15200 \\
\hline 4 & Greece & 27,5 & 23,6 & 17,3 & 18800 & 19300 & 20600 \\
\hline 5 & Denmark & 7,4 & 6,0 & 5,8 & 33700 & 35900 & 38300 \\
\hline 6 & Estonia & 8,6 & 6,8 & 4,5 & 19800 & 21900 & 24700 \\
\hline 7 & Ireland & 13,8 & 8,4 & 5,0 & 34600 & 50300 & 56800 \\
\hline 8 & Spain & 26,1 & 19,6 & 14,1 & 23500 & 26000 & 27700 \\
\hline 9 & Italy & 12,1 & 11,7 & 10,0 & 15900 & 27600 & 28900 \\
\hline 10 & Cyprus & 15,9 & 13,0 & 7,1 & 22100 & 23800 & 26300 \\
\hline 11 & Latvia & 11,9 & 9,6 & 6,3 & 16400 & 18300 & 21300 \\
\hline 12 & Lithuania & 11,8 & 7,9 & 6,3 & 19200 & 21400 & 24500 \\
\hline 13 & Luxembourg & 5,9 & 6,3 & 5,6 & 68700 & 74100 & 77100 \\
\hline 14 & Malta & 6,1 & 4,7 & 3,4 & 22400 & 27100 & 29700 \\
\hline 15 & the Netherlands & 7,3 & 6,0 & 3,4 & 35500 & 36300 & 39100 \\
\hline 16 & Germany & 5,2 & 4,1 & 3,2 & 32600 & 35300 & 37400 \\
\hline 17 & Poland & 10,3 & 6,2 & 3,3 & 17600 & 19400 & 21500 \\
\hline 18 & Portugal & 16,4 & 16,2 & 11,5 & 20100 & 22000 & 23000 \\
\hline 19 & Romania & 7,1 & 5,9 & 3,9 & 14300 & 16900 & 19600 \\
\hline 20 & Slovakia & 14,2 & 9,7 & 5,8 & 20100 & 21900 & 23600 \\
\hline 21 & Slovenia & 10,1 & 8,0 & 4,6 & 21500 & 23500 & 26500 \\
\hline 22 & Hungary & 10,2 & 5,1 & 3,4 & 17600 & 19000 & 21300 \\
\hline 23 & Finland & 8,2 & 8,8 & 6,7 & 29800 & 30900 & 33500 \\
\hline 24 & France & 10,3 & 10,0 & 8,5 & 28500 & 29700 & 31500 \\
\hline 25 & Croatia & 17,4 & 13,4 & 6,8 & 15700 & 17400 & 19100 \\
\hline 26 & Czechia & 7,0 & 4,0 & 2,0 & 22000 & 24900 & 27500 \\
\hline 27 & Sweden & 8,0 & 6,9 & 6,8 & 33000 & 34700 & 36700 \\
\hline & Ukraine & 7,7 & 9,7 & 9,1 & 2989,6 & 2317,6 & 3638,1 \\
\hline Meanyyyyyy value by the EU countries & 11,3 & 9,0 & 6,3 & 25244,4 & 28166,7 & 30559,3 \\
\hline
\end{tabular}

*euro exchange operations made at the average annual rate for each current year

Source: Adapted from Eurostat, Total unemployment rate, 2020; Eurostat, Purchasing power adjusted GDP per capita, 2020; Ministry of Finance of Ukraine, Unemployment rate 2020; Ministry of Finance of Ukraine, Gross Domestic Product, GDP, 2020

The next stage of the methodology algorithm is to normalize indicators to make single system by the formula:

$$
I_{\text {norm }}=\frac{Z_{\text {fact }}-Z_{\min }}{Z_{\max }-Z_{\min }},
$$

where $I_{\text {norm }}$ - normalized indicator;

$Z_{\text {fact }}$ - actual (fact) value;

$Z_{\text {max }}$ - maximum value;

$Z_{\min }$ - minimum value. 
Pereverzieva, A. and Volkov, V. (2020), "Assessment method of social entrepreneurship nature and its development”, Management and entrepreneurship: trends of development, Vol. 1, Issue 11, pp. 113-131, DOI: https://doi.org/10.26661/2522-1566/2020-1/11-08

The results of unemployment rate and income per capita indicators`normalizing in 2013, 2016 and 2019 are illustrated in Table 2.

The Social Entrepreneurship Need Index $\left(I_{S E N I}\right)$ consists of two sib-indices: the Unemployment Rate Index $\left(I_{U N E M P}\right)$ and Per Capita Index $\left(I_{I P C}\right)$. To calculate The Social Entrepreneurship Need Index we apply the multiplicative model, which eliminates the possibility to offset low values of indicators at the expense of higher values of other indicators.

Table 2

Unemployment rate and income per capita indicators`normalizing in 2013, 2016 and 2019

\begin{tabular}{|c|l|c|c|c|c|c|c|}
\hline \multirow{2}{*}{ № } & \multirow{2}{*}{ Country } & \multicolumn{3}{c|}{ Unemployment rate index } & \multicolumn{3}{c|}{ Income per capita index } \\
\cline { 3 - 8 } & & 2013 & 2016 & 2019 & 2013 & 2016 & 2019 \\
\hline 1 & Austria & 0,009 & 0,102 & 0,163 & 0,399 & 0,362 & 0,378 \\
\hline 2 & Belgium & 0,143 & 0,179 & 0,222 & 0,346 & 0,327 & 0,321 \\
\hline 3 & Bulgaria & 0,386 & 0,184 & 0,144 & 0,000 & 0,000 & 0,000 \\
\hline 4 & Greece & 1,000 & 1,000 & 1,000 & 0,120 & 0,091 & 0,087 \\
\hline 5 & Denmark & 0,099 & 0,102 & 0,248 & 0,383 & 0,367 & 0,373 \\
\hline 6 & Estonia & 0,152 & 0,143 & 0,163 & 0,138 & 0,134 & 0,153 \\
\hline 7 & Ireland & 0,386 & 0,224 & 0,196 & 0,399 & 0,605 & 0,672 \\
\hline 8 & Spain & 0,937 & 0,796 & 0,791 & 0,203 & 0,202 & 0,202 \\
\hline 9 & Italy & 0,309 & 0,393 & 0,523 & 0,069 & 0,229 & 0,221 \\
\hline 10 & Cyprus & 0,480 & 0,459 & 0,333 & 0,178 & 0,166 & 0,179 \\
\hline 11 & Latvia & 0,300 & 0,286 & 0,281 & 0,078 & 0,075 & 0,099 \\
\hline 12 & Lithuania & 0,296 & 0,199 & 0,281 & 0,127 & 0,126 & 0,150 \\
\hline 13 & Luxembourg & 0,031 & 0,117 & 0,235 & 1,000 & 1,000 & 1,000 \\
\hline 14 & Malta & 0,040 & 0,036 & 0,092 & 0,183 & 0,221 & 0,234 \\
\hline 15 & the Netherlands & 0,094 & 0,102 & 0,092 & 0,414 & 0,373 & 0,386 \\
\hline 16 & Germany & 0,000 & 0,005 & 0,078 & 0,363 & 0,357 & 0,359 \\
\hline 17 & Poland & 0,229 & 0,112 & 0,085 & 0,099 & 0,093 & 0,102 \\
\hline 18 & Portugal & 0,502 & 0,622 & 0,621 & 0,143 & 0,136 & 0,126 \\
\hline 19 & Romania & 0,085 & 0,097 & 0,124 & 0,041 & 0,051 & 0,071 \\
\hline 20 & Slovakia & 0,404 & 0,291 & 0,248 & 0,143 & 0,134 & 0,136 \\
\hline 21 & Slovenia & 0,220 & 0,204 & 0,170 & 0,168 & 0,161 & 0,183 \\
\hline 22 & Hungary & 0,224 & 0,056 & 0,092 & 0,099 & 0,086 & 0,099 \\
\hline 23 & Finland & 0,135 & 0,245 & 0,307 & 0,314 & 0,284 & 0,296 \\
\hline 24 & France & 0,229 & 0,306 & 0,425 & 0,291 & 0,264 & 0,263 \\
\hline 25 & Croatia & 0,547 & 0,480 & 0,314 & 0,065 & 0,060 & 0,063 \\
\hline 26 & Czechia & 0,081 & 0,000 & 0,000 & 0,176 & 0,184 & 0,199 \\
\hline 27 & Sweden & 0,126 & 0,148 & 0,314 & 0,370 & 0,347 & 0,347 \\
\hline Mean & value by the EU countries & 0,276 & 0,255 & 0,279 & 0,234 & 0,238 & 0,248 \\
\hline & & & & & & & \\
\hline
\end{tabular}

Source: Own calculations formula:

The Social Entrepreneurship Needs Index for a particular country is calculated by the

$$
I_{S E N I}=\sqrt[2]{I_{U N E M P} \times I_{I P C}}
$$

where $I_{S E N I}-$ The Social Entrepreneurship Need Index;

$I_{U N E M P}$ - the Unemployment Rate Index;

$I_{I P C}-$ Per Capita Index. 
The relevance of multiplicative model application is proved by the fact that social entrepreneurship is seen as the way to reduce unemployment rate and raise per capita income at the same time.

Let us calculate the Social Entrepreneurship Need Index according to the multiplicative model for the EU countries (Table 3).

The Social Entrepreneurship Need Index (Table 3) shows that for the vast majority of the EU countries, the issue of social entrepreneurship introduction to solve the problem of unemployment (hypothesis H1) to ensure sufficient standard of living and quality of life (hypothesis H2) is relevant. Only Ireland, Spain, Cyprus, Poland, Slovakia, Slovenia and Croatia have steady tendency to reduce the need for social entrepreneurship. These countries amount for only $25 \%$ of the total number of the EU countries. Thus, it may be stated that there is an increasing need to form and develop such business form as social entrepreneurship.

Table 3

The Social Entrepreneurship Need Index of the EU countries in 2013, 2016 and 2019

\begin{tabular}{|c|l|c|c|c|}
\hline \multirow{2}{*}{ № } & \multirow{2}{*}{ Country } & \multicolumn{3}{|c|}{ Social Entrepreneurship Demand Index } \\
\cline { 3 - 5 } & & 2013 & 2016 & 2019 \\
\hline 1 & Austria & 0,060 & 0,192 & 0,249 \\
\hline 2 & Belgium & 0,223 & 0,242 & 0,267 \\
\hline 3 & Bulgaria & $0,000^{*}$ & $0,000^{*}$ & $0,000^{*}$ \\
\hline 4 & Greece & 0,346 & 0,302 & 0,295 \\
\hline 5 & Denmark & 0,194 & 0,193 & 0,304 \\
\hline 6 & Estonia & 0,145 & 0,139 & 0,158 \\
\hline 7 & Ireland & 0,392 & 0,369 & 0,363 \\
\hline 8 & Spain & 0,436 & 0,401 & 0,400 \\
\hline 9 & Italy & 0,146 & 0,300 & 0,340 \\
\hline 10 & Cyprus & 0,292 & 0,276 & 0,244 \\
\hline 11 & Latvia & 0,153 & 0,146 & 0,166 \\
\hline 12 & Lithuania & 0,194 & 0,158 & 0,205 \\
\hline 13 & Luxembourg & 0,177 & 0,343 & 0,485 \\
\hline 14 & Malta & 0,086 & 0,089 & 0,146 \\
\hline 15 & the Netherlands & 0,198 & 0,195 & 0,188 \\
\hline 16 & Germany & 0,000 & 0,043 & 0,168 \\
\hline 17 & Poland & 0,150 & 0,102 & 0,093 \\
\hline 18 & Portugal & 0,268 & 0,291 & 0,280 \\
\hline 19 & Romania & 0,059 & 0,071 & 0,094 \\
\hline 20 & Slovakia & 0,240 & 0,198 & 0,184 \\
\hline 21 & Slovenia & 0,192 & 0,181 & 0,176 \\
\hline 22 & Hungary & 0,149 & 0,070 & 0,095 \\
\hline 23 & Finland & 0,206 & 0,264 & 0,301 \\
\hline 24 & France & 0,258 & 0,284 & 0,334 \\
\hline 25 & Croatia & 0,189 & 0,169 & 0,141 \\
\hline 26 & Czechia & 0,119 & $0,000^{*}$ & $0,000^{*}$ \\
\hline 27 & Sweden & 0,216 & 0,226 & 0,330 \\
\hline Mean value by the EU countries & 0,198 & 0,203 & 0,232 \\
\hline & & & & \\
\hline
\end{tabular}

Note: *value of indicator «0» for countries characterized by the minimum value of corresponding indicator

Source: Own calculations 
Pereverzieva, A. and Volkov, V. (2020), "Assessment method of social entrepreneurship nature and its development”, Management and entrepreneurship: trends of development, Vol. 1, Issue 11, pp. 113-131, DOI: https://doi.org/10.26661/2522-1566/2020-1/11-08

Important indicator is countries ranking by favourable conditions for the development of social entrepreneurship, among which the key are: government policy support, highly qualified staff with required skills attraction, general public understanding, and chance to "earn" for life, improvement and development, access to investment resources. The value of the indicator for the EU countries is given in Table 4.

Table 4

\section{Index of favourable conditions for the development of social entrepreneurship in the EU countries year-wise}

\begin{tabular}{|l|l|c|c|c|c|}
\hline \multirow{2}{*}{ № } & \multicolumn{2}{|c|}{ Country } & \multicolumn{2}{c|}{$\begin{array}{c}\text { Index of favourable conditions for the } \\
\text { development of social entrepreneurship } \\
\text { year-wise, } \%\end{array}$} & $\begin{array}{c}\text { Index of favourable } \\
\text { conditions for the } \\
\text { development of social } \\
\text { entrepreneurship year-wise } \\
\text { (normalized) }\end{array}$ \\
\cline { 3 - 6 } & & 2016 & 2019 & 2016 & 2019 \\
\hline 1 & Austria & 44,5 & 50,5 & 0,445 & 0,505 \\
\hline 2 & Belgium & 54,8 & 61,7 & 0,548 & 0,617 \\
\hline 3 & Greece & 42,4 & 50,4 & 0,424 & 0,504 \\
\hline 4 & Denmark & 52,2 & 59,6 & 0,522 & 0,596 \\
\hline 5 & Ireland & 35,1 & 43,8 & 0,351 & 0,438 \\
\hline 6 & Spain & 46,9 & 48,7 & 0,469 & 0,487 \\
\hline 7 & Italy & 55,9 & 54,0 & 0,559 & 0,540 \\
\hline 8 & the Netherlands & 51,1 & 59,0 & 0,511 & 0,590 \\
\hline 9 & Germany & 55,9 & 52,9 & 0,559 & 0,529 \\
\hline 10 & Poland & 53,0 & 45,0 & 0,530 & 0,450 \\
\hline 11 & Finland & 51,8 & 58,6 & 0,518 & 0,586 \\
\hline 12 & France & 58,0 & 71,9 & 0,580 & 0,719 \\
\hline 13 & Sweden & 51,9 & 54,6 & 0,519 & 0,546 \\
\hline Mean value by the EU countries & 50,3 & 54,7 & 0,503 & 0,547 \\
\hline
\end{tabular}

Source: Thomson Reuters Foundation, 2016; 2019.

In our opinion, comparison of the demand to start social enterprises and develop them with the conditions created in a certain country confirms the need and possibility of social entrepreneurship strategy implementation.

Let us compare the calculated Social Entrepreneurship Need Index with the ranking of the best countries for the development of social entrepreneurship in 2016 and 2019 (Table 5).

Table 5

Comparative analysis of the EU countries`dynamic pattern for social entrepreneurship

\begin{tabular}{|c|l|c|c|c|c|}
\hline \multirow{2}{*}{ № } & \multirow{2}{*}{ Country } & \multicolumn{2}{|c|}{$\begin{array}{c}\text { The Social Entrepreneurship Need } \\
\text { Index year-wise }\end{array}$} & \multicolumn{2}{c|}{$\begin{array}{c}\text { Index of favourable } \\
\text { conditions for the } \\
\text { development of social } \\
\text { entrepreneurship year-wise } \\
\text { (normalized) }\end{array}$} \\
\hline 1 & & \multicolumn{2}{|c|}{} & 2016 & 2019 \\
\hline 1 & & 2016 & 2019 & 2 & 6 \\
\hline 2 & Austria 2 & 3 & 4 & 5 & 0,505 \\
\hline
\end{tabular}

Table 5 continuation on the next page 
Table 5 continuation

\begin{tabular}{|l|l|c|c|c|c|}
\hline 1 & \multicolumn{1}{|c|}{2} & 3 & 4 & 5 & 6 \\
\hline 3 & Greece & 0,302 & 0,295 & 0,424 & 0,504 \\
\hline 4 & Denmark & 0,193 & 0,304 & 0,522 & 0,596 \\
\hline 5 & Ireland & 0,369 & 0,363 & 0,351 & 0,438 \\
\hline 6 & Spain & 0,401 & 0,400 & 0,469 & 0,487 \\
\hline 7 & Italy & 0,300 & 0,340 & 0,559 & 0,540 \\
\hline 8 & the Netherlands & 0,195 & 0,188 & 0,511 & 0,590 \\
\hline 9 & Germany & 0,043 & 0,168 & 0,559 & 0,529 \\
\hline 10 & Poland & 0,102 & 0,093 & 0,530 & 0,450 \\
\hline 11 & Finland & 0,264 & 0,301 & 0,518 & 0,586 \\
\hline 12 & France & 0,284 & 0,334 & 0,580 & 0,719 \\
\hline 13 & Sweden & 0,247 & 0,263 & 0,519 & 0,546 \\
\hline Mean value by the EU countries & 0,241 & 0,274 & 0,503 & 0,547 \\
\hline
\end{tabular}

\section{Source: own calculations}

Data are grouped in Table 5 for 13 EU countries as the study objective. We should note that the survey covered 46 countries in 2016 and only 43 countries in 2019 . Therefore, we have selected those EU countries, which have the determined rate of favourable environmental for social entrepreneurship development. To provide the analysis, the indicator was normalized since its value was represented in \%.

Homologous series of the EU countries' indicators by the Social Entrepreneurship Need Index and the Index of Favourable Conditions for Social Entrepreneurship Development (fig.2 and fig. 3) were built to demonstrate and compare the EU countries 'indicators with the mean value.

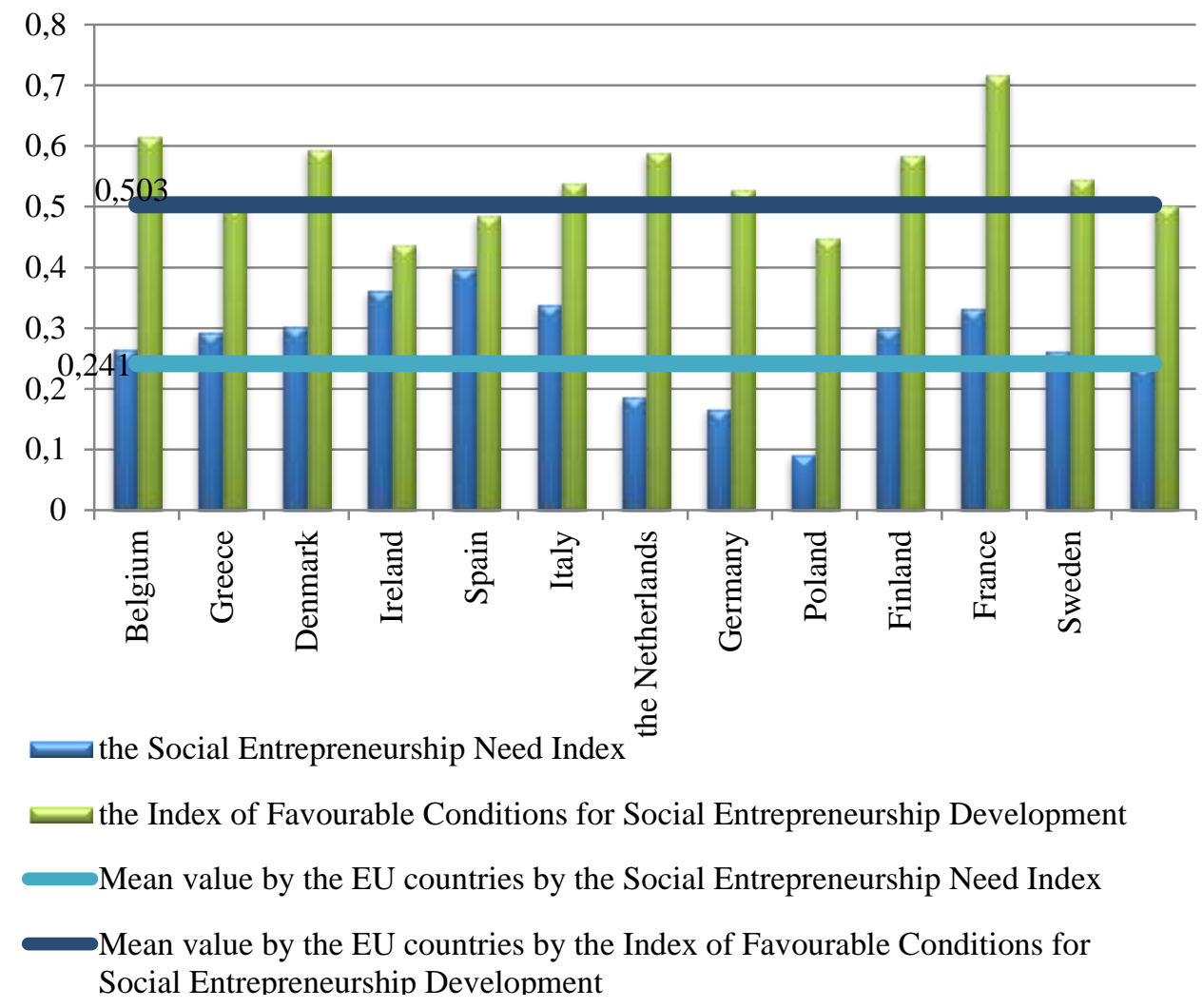

Figure 2. The comparison of the Social Entrepreneurship Need Index and the Index of Favourable Conditions for Social Entrepreneurship Development with the mean value, 2016

Source: Own compilation 
Pereverzieva, A. and Volkov, V. (2020), "Assessment method of social entrepreneurship nature and its development”, Management and entrepreneurship: trends of development, Vol. 1, Issue 11, pp. 113-131, DOI: https://doi.org/10.26661/2522-1566/2020-1/11-08

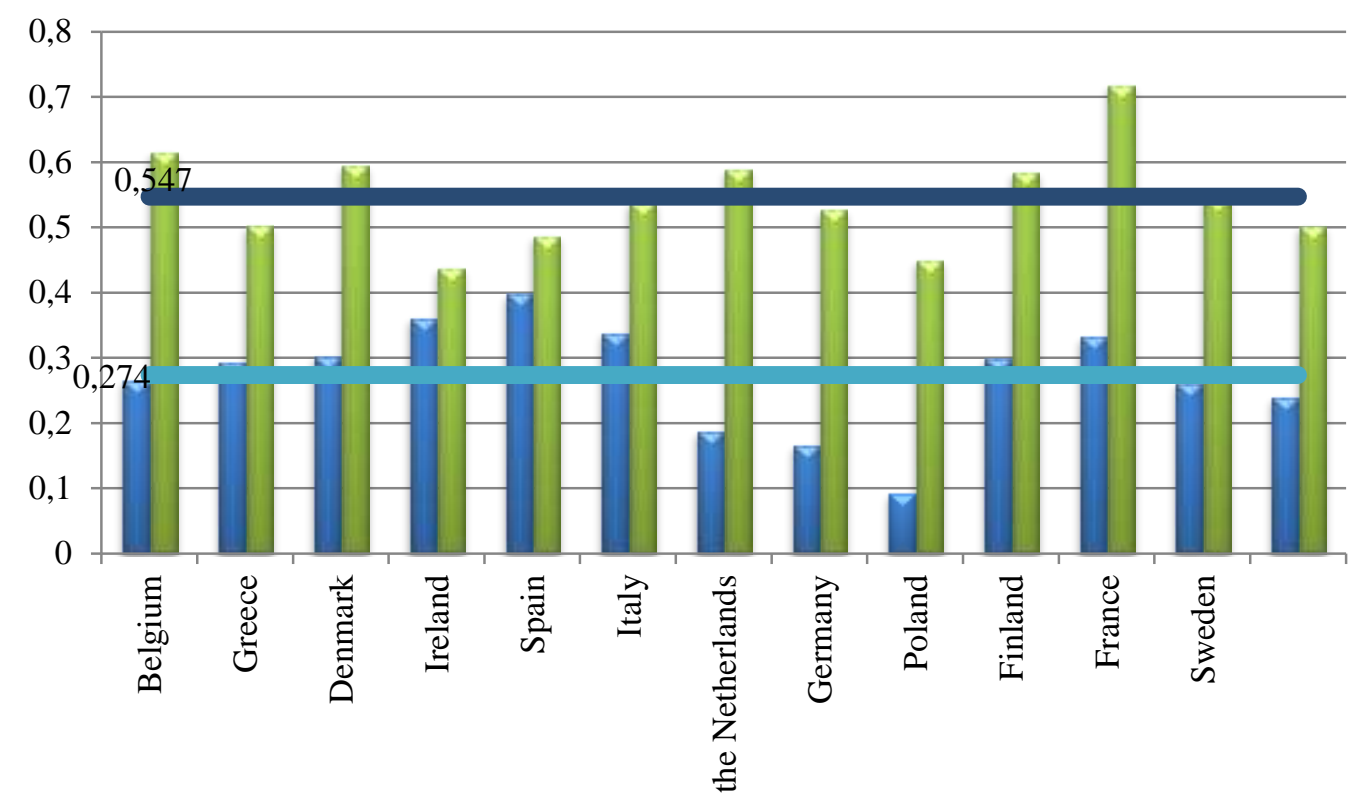

the Social Entrepreneurship Need Index

the Index of Favourable Conditions for Social Entrepreneurship Development

Mean value by the EU countries by the Social Entrepreneurship Need Index

Mean value by the EU countries by the Index of Favourable Conditions for Social Entrepreneurship Development

\section{Figure 3. The comparison of the Social Entrepreneurship Need Index and the Index of Favourable Conditions for Social Entrepreneurship Development with the mean value, 2019}

\section{Source: Own compilation}

Fig. 2 illustrates that in 2016 the Social Entrepreneurship Needs Index exceeded the mean value for 6 EU countries, while the Index of Favourable Conditions for Social Entrepreneurship Development exceeded the mean value for 7 European countries. The situation changed in 2019 (fig. 3): the Social Entrepreneurship Needs Index exceeded the mean value for 7 European countries and the Index of Favourable Conditions for Social Entrepreneurship Development exceeded the mean value for 5 European countries.

Based on the obtained calculations, we make a matrix (Table 6), which consists of four quadrants:

the first quadrant: the Social Entrepreneurship Needs Index is below the mean value and the Index of Favourable Conditions for Social Entrepreneurship Development is higher than the mean value;

second quadrant: The Social Entrepreneurship Needs Index is below the mean value and the Index of Favourable Conditions for Social Entrepreneurship Development is below the mean value;

third quadrant: the Social Entrepreneurship Needs Index is higher than the mean value and the Index of Favourable Conditions for Social Entrepreneurship Development is higher the mean value;

fourth quadrant: The Social Entrepreneurship Needs Index is higher than the mean value and the Index of Favourable Conditions for Social Entrepreneurship Development is below the mean value. 
Table 6

Matrix of comparison of countries`economies according to the Social Entrepreneurship Need Index and Index of Favourable Conditions for Social Entrepreneurship Development in 2016 and 2019

\begin{tabular}{|c|c|c|c|c|}
\hline \multirow[b]{2}{*}{ Index } & \multicolumn{2}{|c|}{2016} & \multicolumn{2}{|c|}{2019} \\
\hline & $\begin{array}{l}\text { the Index of } \\
\text { Favourable } \\
\text { Conditions for } \\
\text { Social } \\
\text { Entrepreneurship } \\
\text { Development is } \\
\text { higher than the } \\
\text { mean value }\end{array}$ & $\begin{array}{l}\text { the Index of } \\
\text { Favourable } \\
\text { Conditions for } \\
\text { Social } \\
\text { Entrepreneurship } \\
\text { Development is } \\
\text { below the mean } \\
\text { value }\end{array}$ & $\begin{array}{l}\text { the Index of } \\
\text { Favourable } \\
\text { Conditions for } \\
\text { Social } \\
\text { Entrepreneurship } \\
\text { Development is } \\
\text { higher than the } \\
\text { mean value }\end{array}$ & $\begin{array}{l}\text { the Index of } \\
\text { Favourable } \\
\text { Conditions for } \\
\text { Social } \\
\text { Entrepreneurship } \\
\text { Development is } \\
\text { below the mean } \\
\text { value }\end{array}$ \\
\hline $\begin{array}{l}\text { The Social } \\
\text { Entrepreneurship } \\
\text { Needs Index is } \\
\text { below the mean } \\
\text { value }\end{array}$ & $\begin{array}{l}\text { I quadrant } \\
\text { Denmark, } \\
\text { Italy, } \\
\text { the Netherlands, } \\
\text { Germany, } \\
\text { Poland }\end{array}$ & $\begin{array}{c}\text { II quadrant } \\
\text { Austria }\end{array}$ & $\begin{array}{c}\text { I quadrant } \\
-\end{array}$ & $\begin{array}{l}\text { II quadrant } \\
\text { Austria, } \\
\text { Greece, } \\
\text { Ireland, } \\
\text { Spain }\end{array}$ \\
\hline $\begin{array}{l}\text { the Social } \\
\text { Entrepreneurship } \\
\text { Needs Index is } \\
\text { higher than the } \\
\text { mean value }\end{array}$ & $\begin{array}{l}\text { IV quadrant } \\
\text { Belgium, } \\
\text { Finland, } \\
\text { France, } \\
\text { Sweden }\end{array}$ & $\begin{array}{l}\text { III quadrant } \\
\text { Greece, } \\
\text { Ireland, } \\
\text { Spain }\end{array}$ & $\begin{array}{c}\text { IV quadrant } \\
\text { Belgium, } \\
\text { Denmark, } \\
\text { Italy, } \\
\text { the Netherlands, } \\
\text { Finland, } \\
\text { France }\end{array}$ & $\begin{array}{l}\text { III quadrant } \\
\text { Germany, } \\
\text { Poland }\end{array}$ \\
\hline
\end{tabular}

\section{Source: Own compilation}

The Matrix of Countries`Economic Comparison (Table 6) shows that five EU countries faced the need of social entrepreneurship and created favourable conditions for it in 2016, namely Denmark, Italy, the Netherlands, Germany and Poland. The opposite was the case in 2019. However, many European countries had favourable conditions for the development of social entrepreneurship in 2019. Austria, Greece, Ireland, and Spain were added to Austria. Advantageous situation in 2019 is characterized by larger number of countries in need of social entrepreneurship development, which created favourable environment for it, namely Belgium, Denmark, Italy, the Netherlands, Finland and France.

In order to analyze the changing trends in social entrepreneurship, we build the matrix of the EU countries` ranking shift in 2016 and 2019 with a lag of three year. 
Pereverzieva, A. and Volkov, V. (2020), "Assessment method of social entrepreneurship nature and its development”, Management and entrepreneurship: trends of development, Vol. 1, Issue 11, pp. 113-131, DOI: https://doi.org/10.26661/2522-1566/2020-1/11-08

Table 7

\begin{abstract}
Matrix of the EU countries`ranking shift by calculated indices in 2016 and 2019 with a lag of three years
\end{abstract}

\begin{tabular}{|c|c|c|c|c|c|}
\hline \multirow[b]{2}{*}{ Indices } & \multicolumn{5}{|c|}{$2016 \rightarrow 2019$} \\
\hline & \multicolumn{2}{|c|}{$\begin{array}{c}\text { the Index of Favourable } \\
\text { Conditions for Social } \\
\text { Entrepreneurship Development is } \\
\text { higher than the mean value }\end{array}$} & \multicolumn{3}{|c|}{$\begin{array}{c}\text { the Index of Favourable } \\
\text { Conditions for Social } \\
\text { Entrepreneurship Development is } \\
\text { below the mean value }\end{array}$} \\
\hline \multirow{3}{*}{$\begin{array}{l}\text { The Social Entrepreneurship } \\
\text { Needs Index is below the mean } \\
\text { value }\end{array}$} & \multicolumn{2}{|c|}{ I quadrant } & \multicolumn{3}{|c|}{ II quadrant } \\
\hline & Germany, Poland & 2016 & Spain & Sreece, Ireland & 2019 \\
\hline & $\begin{array}{l}\text { Denmark, the } \\
\text { Netherland, Italy }\end{array}$ & 2016 & & & \\
\hline \multirow{4}{*}{$\begin{array}{l}\text { The Social Entrepreneurship } \\
\text { Needs Index is higher than the } \\
\text { mean value }\end{array}$} & \multirow{2}{*}{\multicolumn{2}{|c|}{ IV quadrant }} & \multicolumn{3}{|c|}{ III quadrant } \\
\hline & & & 2016 & \multicolumn{2}{|c|}{ Spain, Greece, Ireland } \\
\hline & $\begin{array}{l}\text { Denmark, the } \\
\text { Netherland, Italy }\end{array}$ & 2019 & \multirow{2}{*}{\multicolumn{2}{|c|}{ Germany, Poland }} & \\
\hline & & & & & 2019 \\
\hline
\end{tabular}

\title{
Source: Own compilation
}

Analysis of the countries` dynamics pattern shows the next shifts:

1. Germany and Poland shifted the Ist quadrant in 2016 to the IIId quadrant in 2019. It indicates the growing demand for social entrepreneurship development without appropriate favourable conditions;

2. Denmark, the Netherland and Italy moved from the Ist quadrant in 2016 to the IV quadrant in 2019. The countries face growing need for the formation and development of social entrepreneurship. They simultaneously form advantageous conditions for these business entities activity;

3. Spain, Greece and Ireland moved from the IIId quadrant in 2016 to the IInd quadrant in 2019. The need for social entrepreneurship development was contracting. The countries did not pay attention for the environment of business with a human face.

Other EU countries did not change their policy as for the social entrepreneurship development and, thus, remained in the same quadrants of the matrix.

The proposed methodology application to assess nature and development of social entrepreneurship allowed identifying the growing role and importance of social entrepreneurship for the economies of the most of the EU countries and the world economy as a whole. Two issues were studied as they can be solved by creating social enterprise system: the ways of unemployment rate reduction and per capita income growth were proposed. The results of the study showed that the EU countries with high unemployment rate and low per capita income need additional number of social enterprises, but they do not always have favourable conditions for their functioning and further development. The number of issues and understanding of their content, possibilities of their solution at the expense of social enterprises are controversial and form the basis for the further research.

Particular value of our research inheres in the opportunity for the national economy to choose European model of social entrepreneurship, characterized by the dominance of non-commercial goals over commercial ones, relevance of their optimal correlation and countries` increased economic sustainability in the face of global challenges. 


\section{CONCLUSION}

A new method to assessing nature and development of social entrepreneurship, as well as perspectives of its further progress, determined by the creation of favourable environment for business with a human face have been proposed in the article. Assessment methodology has been tested on the example of the EU countries as a group of countries with a similar model of social entrepreneurship placing a much higher importance on non-profit achievements. The results obtained allowed us to demonstrate differences between countries, despite belonging to one business model of social entrepreneurship.

To implement the proposed assessment method, we identified a clear sequence of actions in the form of a science-based algorithm that can be used as a universal tool for more indicators related to the study issues and could be solved by social enterprises. The Social Entrepreneurship Needs Index was calculated with a lag of three years for 2013, 2016 and 2019.

The Matrix of comparison of countries`economies according to the Social Entrepreneurship Need Index and Index of Favourable Conditions for Social Entrepreneurship Development in 2016 and 2019 indicated that a third of European economies have changed their attitude to social entrepreneurship. The results show that some countries` need for social enterprises has increased, but they do not have favourable conditions for their development (Germany, Poland). Spain, Greece and Ireland are improving environment for the innovative business form, but at the same time, the need for it is being diminished. In response to the growing need for social enterprises, Denmark, the Netherlands and Italy are creating an advantageous environment for social enterprises`activity and development, in particular, they are shaping their social economies.

As a result of our study the proposed hypotheses have been confirmed: H1 - higher unemployment rate requires enhancing development of social entrepreneurship, $\mathrm{H} 2$ - higher income levels reduce the need for social entrepreneurship, H3 - the more favourable environment for social entrepreneurship a country has, the less is need for it. The first two hypotheses were confirmed by the analysis of statistics on unemployment rate and per capita income in the EU countries. The third hypothesis has been partially confirmed, since the pattern characterizes most of the EU countries, but there are exceptions depend on country`s particularities and its domestic policy. Further research inheres in the increased number of indicators for the analysis that determine the possibility of solving a particular social issue, taking into account national peculiarities, strategic trends of national development and rising welfare.

\section{REFERENCES}

Battilana, J. and Lee, M. (2014), "Advancing Research on Hybrid Organizing - Insights from the Study of Social Enterprises", The Academy of Management Annals, Vol. 8, Issue 1, pp.397441, available at: http://dx.doi.org/10.1080/19416520.2014.893615 (Accessed 16 March 2020), DOI: $10.1080 / 19416520.2014 .893615$

Berezyak, J. (2014), "Foreign experience and domestic realities formation of social entrepreneurship". Scientific Proceedings of the National University of "Ostroh Academy". Economics, Issue 25, pp. 31-36, available at: https://eprints.oa.edu.ua/2998/1/Berezyak_ZN_Vyp_25.pdf (Accessed 13 March 2020), (in Ukrainian).

Byungchae, J. (2019), "The Practical Intelligence of Social Entrepreneurs: Managing the Hybridity of Social Enterprises", Entrepreneurship Research Journal, Vol. 10, Issue 1, available at: https://doi.org/10.1515/erj-2018-0007 (Accessed 18 March 2020), DOI: 10.1515/erj-20180007

Chandra, Y. (2017), "Social entrepreneurship as emancipatory work", Journal of Business Venturing, Vol. 32, Issue 6, pp. 657-673, available at: 
Pereverzieva, A. and Volkov, V. (2020), "Assessment method of social entrepreneurship nature and its development”, Management and entrepreneurship: trends of development, Vol. 1, Issue 11, pp. 113-131, DOI: https://doi.org/10.26661/2522-1566/2020-1/11-08

http://dx.doi.org/10.1016/j.jbusvent.2017.08.004 (Accessed 17 March 2020), DOI: 10.1016/j.jbusvent.2017.08.004

Corner, P.D. and Kearins, K. (2018), "Scaling-up social enterprises: The effects of geographic context", Journal of Management \& Organization, pp. 1-19, available at: http://dx.doi.org/10.1017/jmo.2018.38 (Accessed 16 March 2020), DOI: 10.1017/jmo.2018.38

Dacin, M.T., Dacin, P.A. and Tracey, P. (2011), "Social Entrepreneurship: A Critique and Future Directions", Organization Science, Vol. 22, Issue 5, pp. 1203-1213, available at: http://dx.doi.org/10.1287/orsc.1100.0620 (Accessed 17 March 2020), DOI: 10.1287 /orsc. 1100.0620

Dahiya, V.S. (2019), "Social entrepreneurship as an antidote to state and market failure", Economic and Political Weekly. Vol. 54, Issue 51, available at: https://www.epw.in/engage/article/social-entrepreneurship-antidote-to-state-and-marketfailure (Accessed 17 March 2020).

Eurostat (2020), GDP per capita in EU, available at: https://ec.europa.eu/eurostat/databrowser/view/sdg_10_10/default/table?lang=en (Accessed 17 March 2020).

Eurostat (2020), Unemployment rate in EU, available at: https://ec.europa.eu/eurostat/databrowser/view/tps00203/default/table?lang=en (Accessed 17 March 2020).

Grimes, M.G. et al. (2013), "Studying the Origins of Social Entrepreneurship: Compassion and the Role of Embedded Agency", Academy of Management Review, Vol. 38, Issue 3, pp. 460-463, available at: http://dx.doi.org/10.5465/amr.2012.0429 (Accessed 18 March 2020), DOI: 10.5465/amr.2012.0429

Halushka, Z. (2013), "The phenomenon of social enterprise: concepts and prospects of development in Ukraine", Bulletin of Taras Shevchenko National University of Kyiv. Economics, Issue 148, pp. 15-17, available at: http://dx.doi.org/10.17721/1728-2667.2013/148-2/4 (Accessed 13 March 2020), (in Ukrainian), DOI: 10.17721/1728-2667.2013/148-2/4

International Labour Organization (2018), World Employment and Social Outlook: Trends 2018. International Labour Office - Geneva: ILO, 2018, 82 p., available at: https://www.ilo.org/global/research/global-reports/weso/2018/lang--en/index.htm (Accessed 17 March 2020).

Kirieieva, O. B. (2010), "Social enterprise as instrument of public social policy", Aktual'ni problemy derzhavnoho upravlinnia ta mistsevoho samovriaduvannia, Vol. 3, Issue 6, available at: www.dridu.dp.ua/zbirnik/2011-02(6)/11kobdsp.pdf (Accessed 17 March 2020), (in Ukrainian).

Ministry of Finance of Ukraine (2020), GDP per capita in. Ukraine, available at: https://index.minfin.com.ua/economy/gdp/ (Accessed 23 March 2020).

Ministry of Finance of Ukraine (2020), Unemployment rate in Ukraine, available at: https://index.minfin.com.ua/labour/unemploy/ (Accessed 25 March 2020).

Singh, K. K. (2020), "Social Entrepreneurship, Intrapreneurship, and Social Value Creation: Relevance for Contemporary Social Work Practice", Human Service Organizations: Management, Leadership \& Governance, Vol. 44, Issue 1, pp. 92-95, available at: http://dx.doi.org/10.1080/23303131.2019.1702603 (Accessed 17 March 2020), DOI: 10.1080/23303131.2019.1702603

Thomson Reuters Foundation (2016), The best countries to be a social entrepreneur 2016, available at: http://poll2016.trust.org/ (Accessed 17 March 2020).

Thomson Reuters Foundation (2019), The best countries to be a social entrepreneur 2019, available at: http://poll2019.trust.org/ (Accessed 17 March 2020).

Udodova, V. and Shapoval, V. (2013), "The research of functioning experience of national models of social enterprises", The Journal of V. N. Karazin Kharkiv National University Series: 
“International Relations. Economics. Country Studies. Tourism”, Issue 1042, pp. 105-108, available at: https://periodicals.karazin.ua/irtb/article/view/6165 (Accessed 18 March 2020), (in Ukrainian).

World Bank (2018), Poverty and Shared Prosperity 2018, available at: https://www.worldbank.org/en/publication/poverty-and-shared-prosperity (Accessed 17 March 2020).

\section{СПИСОК ВИКОРИСТАНИХ ДЖЕРЕЛ}

Battilana J. та Lee M. (2014) Advancing Research on Hybrid Organizing - Insights from the Study of Social Enterprises. The Academy of Management Annals. 8(1). 2014. DOI: 10.1080/19416520.2014.893615

Березяк I. I. Зарубіжний досвід та вітчизняні реалії становлення соціального підприємництва. Наукові записки Національного університету «Острозька академія». Серія «Економіка» : збірник наукових праць. 2014. Випуск 25. С. 31-36.

Byungchae, Jin (2019) The Practical Intelligence of Social Entrepreneurs: Managing the Hybridity of Social Enterprises. Published Online: 2019-04-24. DOI: https://doi.org/10.1515/erj-20180007.

Chandra Y. Social Entrepreneurship as Emancipatory Work. Journal of Business Venturing forthcoming. 2017. DOI: 10.1016/j.jbusvent.2017.08.004.

Corner, P.D., Kearins, K. (2018) Scaling-up social enterprises. The effects of geographic context. Journal of Management and Organization. 1-19.

Dacin T., Dacin M., Tracey P. (2011) Social entrepreneurship: A critique and future directions. Organization Science. 22 (5). 1203-1213.

Dahiya, V.S. (2019) Social entrepreneurship as an antidote to state and market failure. Economic and Political Weekly. 54(51).

Eurostat (2020). Unemployment rate in EU. URL: https://ec.europa.eu/eurostat/databrowser/view/tps00203/default/table?lang=en ～(дата звернення: 17.03.2020).

Eurostat (2020). GDP per capita in EU. URL: https://ec.europa.eu/eurostat/databrowser/view/sdg_10_10/default/table?lang=en _ (дата звернення: 17.03.2020).

Grimes M., Vogus T. J. McMullen J.S., Miller T.L. (2013) Studying the Origins of Social Entrepreneurship: Compassion and the Role of Embedded Agency. The Academy of Management Review. 38(3): 2013. 460-463. DOI: 10.5465/amr.2012.0429.

Галушка 3. I. Феномен соціального підприємництва: поняття та перспективи розвитку в Україні. Вісник Київського національного університету імені Тараса Шевченка. Економіка. 2013. Вип. 148. С. 15-17.

International Labour Organization (2018). World Employment and Social Outlook: Trends 2018. International Labour Office - Geneva: ILO, 2018. 82 p. URL: https://www.ilo.org/global/research/global-reports/weso/2018/lang--en/index.htm ～(дата звернення: 17.03.2020).

Кірєєва О.Б. Соціальне підприємництво як інструмент державної соціальної політики. Актуальні проблеми державного управління та місиевого самоврядування: зб. наук. пр. Дніпропетровськ : ДРІДУ НАДУ. 2010. Вип. 3 (6). URL: www.dridu.dp.ua/zbirnik/201102(6)/11kobdsp.pdf (дата звернення: 17.03.2020).

Ministry of Finance of Ukraine (2020). Unemployment rate in Ukraine. URL: https://index.minfin.com.ua/labour/unemploy/ (дата звернення: 23.03.2020).

Ministry of Finance of Ukraine (2020). GDP per capita in. Ukraine. URL: https://index.minfin.com.ua/economy/gdp/ (дата звернення: 25.03.2020). 
Pereverzieva, A. and Volkov, V. (2020), "Assessment method of social entrepreneurship nature and its development”, Management and entrepreneurship: trends of development, Vol. 1, Issue 11, pp. 113-131, DOI: https://doi.org/10.26661/2522-1566/2020-1/11-08

Singh, K.K. "Social Entrepreneurship, Intrapreneurship, and Social Value Creation: Relevance for Contemporary Social Work Practice", Human Service Organizations: Management, Leadership \& Governance, 2020, 44(1), pp. 92-95. URL: http://dx.doi.org/10.1080/23303131.2019.1702603 (дата звернення: 17.03.2020).

Thomson Reuters Foundation (2016). The best countries to be a social entrepreneur 2016. URL: http://poll2016.trust.org/ (дата звернення: 17.03.2020).

Thomson Reuters Foundation (2019). The best countries to be a social entrepreneur 2019. URL: http://poll2019.trust.org/ (дата звернення: 17.03.2020).

Удодова В.І., Шаповал В.І. Дослідження досвіду функціонування національних моделей соціального підприємництва. Вісник Харківського національного університету ім. В. Н. Каразіна. 2013. № 1042. С. 105-108.

World Bank (2018). Poverty and Shared Prosperity 2018. URL: https://www.worldbank.org/en/publication/poverty-and-shared-prosperity (дата звернення: 17.03.2020).

\section{МЕТОД ОЦІНКИ СТАНУ ТА РОЗВИТКУ СОЦІАЛЬНОГО ПІДПРИЕМНИЦТВА}

\author{
Переверзсва Анна Василівна \\ Запорізький начіональний університет \\ м. Запоріжжя, Украӥна
}

\author{
Волков Володимир Петрович \\ Запорізький наиіональний університет \\ м. Запоріжжя, Украӥна
}

Актуальність дослідження соціального підприємництва та оцінки потреби в ньому обумовлена загостренням соціально-економічних проблем, пов'язаних із зниженням рівня платоспроможності населення та неможливістю їх вирішення на державному рівні. Необхідність впровадження та розвитку соціального підприємництва потребує створення сприятливих умов у країні, що передбачає врахування таких чинників як державна підтримка, сприйняття суспільством та наявність потенційних інвесторів. Існування такого феномену в економіці як соціальне підприємництво має дуальну природу: сприяє повному задоволенню базових потреб населення та забезпечує самореалізацію соціального підприємця. Соціальне підприємство орієнтується в своїй діяльності на реалізацію некомерційних та комерційних цілей. Особливістю європейської моделі соціального підприємництва $є$ домінування некомерційної складової. Оцінка стану та можливостей функціонування й розвитку соціальних підприємств дозволяє досягати принципу збалансованості «потреби-можливості» 3 метою прийняття ефективних управлінських рішень щодо доцільності запровадження такої форми господарювання в країні. Якщо $\epsilon$ потреба в соціальному підприємництві, то, відповідно, перед економікою країни постає питання формування сприятливого середовища для його функціонування та розвитку.

Метою дослідження є запропонувати спосіб оцінки стану та розвитку соціального підприємництва, необхідності його запровадження в країнах та виокремлення умов для розвитку, що дозволяє вирішити соціально-економічні проблеми та рухатися в напрямі побудови економіки з «людським обличчям».

Предметом дослідження $\epsilon$ наукові та практичні основи розвитку соціального підприємництва в контексті співвідношення необхідності його запровадження та умов функціонування.

Методологія: у дослідженні був використаний комплексний підхід до оцінки, котрий передбачає застосування різних методів, а саме: індексний метод (для розрахунку субіндексів та загального індексу і приведення даних до єдиної системи для зручності порівняння); матричний метод (групування країн залежно від зміни позиції щодо потреби в соціальному підприємництві); мультиплікативна модель (аналітичний інструментарій для визначення загального індексу, що дозволяє оцінити внесок кожного індикатора одночасно). 
Результатом дослідження $є$ спосіб оцінки стану та умов розвитку соціального підприємництва, який практично реалізований на прикладі країн СС.

Висновки: визначено, що за період 2016, 2019 рр. із трирічним лагом третина європейських країн змінили своє ставлення до соціального підприємництва. Для деяких країн зросла потреба в соціальних підприємствах, але не створені сприятливі умови їх розвитку; інші країни покращують умови для діяльності соціальних підприємств, але при цьому зменшується потреба в них; зростання потреби в соціальних підприємствах у третині країн супроводжується створенням сприятливого середовища для їх діяльності та розвитку.

Наукова та практична значущість полягає в можливості використання запропонованого методу оцінки для будь-якої країни світу або групи країн із приблизно однаковим рівним розвитку економіки для обгрунтування доцільності запровадження такої інноваційної форми господарювання як соціальне підприємництво, i, відповідно, визначення умов, котрі потрібно створити для його сприятливого розвитку в довгостроковій перспективі, розробки стратегії функціонування соціальних підприємств та управління ними.

Ключові слова: соціальне підприємництво, індекс, країни $\mathrm{CC}$, розвиток, потреба в соціальному підприємництві, середовище функціонування бізнесу з «людським обличчям».

\section{МЕТОД ОЦЕНКИ СОСТОЯНИЯ И РАЗВИТИЯ СОЦИАЛЬНОГО ПРЕДПРИНИМАТЕЛЬСТВА}

Переверзева Анна Васильевна

Запорожский начиональный университет, 2. Запорожье, Украина
Волков Владимир Петрович

Запорожский национальный университет, 2. Запорожье, Украина

Актуальность исследования социального предпринимательства и оценки потребности в нем обусловлена обострением социально-экономических проблем, связанных со снижением уровня платежеспособности населения и невозможностью их решения на государственном уровне. Необходимость внедрения и развития социального предпринимательства требует создания благоприятных условий в стране, что предполагает учет таких факторов, как государственная поддержка, восприятие обществом и наличие потенциальных инвесторов. Существование такого феномена в экономике как социальное предпринимательство имеет дуальную природу: способствует полному удовлетворению базовых потребностей населения и обеспечивает самореализацию социального предпринимателя. Социальное предприятие ориентируется в своей деятельности на реализацию некоммерческих и коммерческих целей. Особенностью европейской модели социального предпринимательства является доминирование некоммерческой составляющей. Оценка состояния и возможностей функционирования и развития социальных предприятий позволяет достигать принципа сбалансированности «потребности-возможности» с целью принятия эффективных управленческих решений относительно целесообразности введения такой формы хозяйствования в стране. Если есть потребность в социальном предпринимательстве, то, соответственно, перед экономикой страны стоит вопрос формирования благоприятной среды для его функционирования и развития.

Целью исследования является предложить способ оценки состояния и развития социального предпринимательства, необходимости его введения в странах и выделения условий для развития, что позволяет решить социально-экономические проблемы и двигаться в направлении построения экономики с «человеческим лицом».

Предметом исследования являются научные и практические основы развития социального предпринимательства в контексте соотношения необходимости его введения и условий функционирования.

Методология: в исследовании был использован комплексный подход к оценке, который предусматривает применение различных методов, а именно: индексный метод (для расчета 
Pereverzieva, A. and Volkov, V. (2020), "Assessment method of social entrepreneurship nature and its development", Management and entrepreneurship: trends of development, Vol. 1, Issue 11, pp. 113-131, DOI: https://doi.org/10.26661/2522-1566/2020-1/11-08

субиндексов и общего индекса и приведение данных к единой системе для удобства сравнения); матричный метод (группировка стран в зависимости от изменения позиции относительно потребности в социальном предпринимательстве); мультипликативная модель (аналитический инструментарий для определения общего индекса, что позволяет оценить вклад каждого индикатора одновременно).

Результатом исследования является способ оценки состояния и условий развития социального предпринимательства, который практически реализован на примере стран ЕС.

Выводы: определено, что за период 2016, 2019 гг. с трехлетним лагом треть европейских стран изменили свое отношение к социальному предпринимательству. Для некоторых стран возросла потребность в социальных предприятиях, но не созданы благоприятные условия их развития; другие страны улучшают условия для деятельности социальных предприятий, но при этом уменьшается потребность в них; рост потребности в социальных предприятиях в трети стран сопровождается созданием благоприятной среды для их деятельности и развития.

Научная и практическая значимость заключается в возможности использования предложенного метода оценки для любой страны мира или группы стран с примерно одинаковым уровнем развития экономики для обоснования целесообразности внедрения такой инновационной формы хозяйствования как социальное предпринимательство, и, соответственно, определения условий, нужно создать для его благоприятного развития в долгосрочной перспективе, разработки стратегии функционирования социальных предприятий и управления ими.

Ключевые слова: социальное предпринимательство, индекс, страны ЕС, развитие, потребность в социальном предпринимательстве, среда функционирования бизнеса с «человеческим лицом». 